Instrumental A chievements

\title{
Crystal Structure of 2(3H)-Benzoxazolone-3-propionitrile
}

\author{
Şebnem Kandil İngeç, ${ }^{*}$ Hüseyin Soylu, Engin Kendi, ${ }^{* *}$ Tijen ÖnKol, ${ }^{* * *}$ and M. Fethi ŞAHín*** \\ *Gazi University, Gazi Education Faculty, Physics Department, 06500 Besevler, Ankara, Turkey \\ **Hacettepe University, Department of Engineering Physics, 06532, Beytepe, Ankara, Turkey \\ ***Gazi University, Department of Pharmaceutical Chemistry, Faculty of Pharmacy, \\ 06330, Hipodrom, Ankara, Turkey
}

(Received February 17, 2000; Accepted May 18, 2000)

The aim of this X-ray diffraction study was to elucidate the crystal structure of benzoxazolone having propionitrile. To 500 $\mathrm{ml}$ of water were added $0.25 \mathrm{~mol}$ of 2-benzoxazolone, $0.3 \mathrm{~mol}$ of triethylamine, and $0.3 \mathrm{~mol}$ of acrylonitrile. The mixture was heated at $50-60^{\circ} \mathrm{C}$ for $6 \mathrm{~h}$ and then stirred at room temperature for $18 \mathrm{~h}$. At the end of this time, the solid material precipitated was filtered, washed with water to become neutral to turnusol paper, dried and crystallized from methanol $\left(\mathrm{mp} .120^{\circ} \mathrm{C}\right)$. The cell dimensions were determined from the angular settings of 25 reflections obtained from an Enraf-Nonius CAD-4 diffractometer. The space group $P 2_{1} / n$ was determined from the systematic absences. Intensity data were collected in the range $2.2<\theta<74.3$ with variable-speed $\omega / 2 \theta$ scans using graphitemonochromated $\mathrm{Cu} \mathrm{K}_{\alpha}$ radiation. Three standard reflections

Table 1 Crystal and experimental data

\footnotetext{
Formula: $\mathrm{C}_{10} \mathrm{H}_{8} \mathrm{~N}_{2} \mathrm{O}_{2}$

Formula weight $=188.18$

Crystal system: monoclinic

Space group: $P 2_{1} / n \quad Z=4$

$a=11.308(1) \AA$

$b=5.8389(3) \AA$

$c=13.931(2) \AA$

$V=890.5(2) \AA^{3}$

$D_{\mathrm{x}}=1.404 \mathrm{~g} / \mathrm{cm}^{3}$

$\mu(\mathrm{Cu} \mathrm{K} \alpha)=0.835 \mathrm{~mm}^{-1}$

$T=295 \mathrm{~K}$

Color: ivory

$F\left(\begin{array}{lll}0 & 0 & 0\end{array}\right)=392$

Radiation $=1.5418 \AA\left(\mathrm{Cu} \mathrm{K}_{\alpha}\right)$

$\theta_{\max }=74.3^{\circ}$

$R=0.048$

$w R=0.1182$

$h k l: h 0 / 14, k 0 / 7, l-17 / 16$

No. of reflections measured $=1809$

No. of reflections used $=1661[\mathrm{~F}>2 \sigma(I)]$

No. of parameters $=160$

Goodness-of-fit $=1.137$

$(\Delta / \sigma)_{\max }=0.021$

$(\Delta \rho)_{\max }=0.265 \mathrm{e}^{-3}$

$(\Delta \rho)_{\min }=-0.206 \mathrm{e}^{-3}$

Measurements: Enraf-Nonius CAD-4 diffractometer

Refinement: full matrix least-squares (SHELXL-97)

Program system: CAD-4 EXPRESS Software

Structure determination: SHELXS-97

Treatment of hydrogen atoms: geometric calculation
}

were monitored at intervals of $120 \mathrm{~min}$. Data were corrected for an intensity variation of $2 \%$. The crystal and experimental data are listed in Table 1. The crystal structure was solved by a direct method using SHELXS-97, ${ }^{1}$ and was refined by a fullmatrix least-squares method using SHELXL-97² with anisotropic temperature factors for non- $\mathrm{H}$ atoms. The hydrogen atoms were located geometrically.

The final coordinates and equivalent thermal parameters for non-hydrogen atoms are given in Table 2; selected bond distances and angles are given in Table 3 . The molecular structure of the title compound (Fig. 1) is shown in Fig. 2. The bond lengths and angles are in good agreement with the literature. ${ }^{3,4}$ All atoms,

Table 2 Final coordinates and equivalent isotropic thermal parameters for non-hydrogen atoms

\begin{tabular}{ccccc}
\hline Atom & $x$ & $y$ & $z$ & $U_{\text {eq }} / \AA^{2}$ \\
\hline O1 & $0.9905(2)$ & $0.1802(3)$ & $0.5874(1)$ & $0.0564(5)$ \\
O2 & $0.8191(2)$ & $0.1787(3)$ & $0.6435(2)$ & $0.0683(6)$ \\
N1 & $0.9584(2)$ & $0.4781(3)$ & $0.6765(1)$ & $0.0485(5)$ \\
N2 & $0.9289(3)$ & $0.2260(5)$ & $0.9116(2)$ & $0.0831(8)$ \\
C1 & $1.0858(2)$ & $0.3330(4)$ & $0.5949(2)$ & $0.0485(6)$ \\
C2 & $1.1838(2)$ & $0.3136(4)$ & $0.5533(2)$ & $0.0567(6)$ \\
C3 & $1.2666(2)$ & $0.4941(5)$ & $0.5716(2)$ & $0.0591(7)$ \\
C4 & $1.2510(2)$ & $0.6801(5)$ & $0.6296(2)$ & $0.0587(6)$ \\
C5 & $1.1505(2)$ & $0.6980(4)$ & $0.6706(2)$ & $0.0528(6)$ \\
C6 & $1.0685(2)$ & $0.5195(3)$ & $0.6511(1)$ & $0.0443(5)$ \\
C7 & $0.9117(2)$ & $0.2732(4)$ & $0.6374(2)$ & $0.0514(6)$ \\
C8 & $0.8947(2)$ & $0.6324(4)$ & $0.7281(2)$ & $0.0530(6)$ \\
C9 & $0.9489(2)$ & $0.6304(4)$ & $0.8402(2)$ & $0.0552(6)$ \\
C10 & $0.9377(2)$ & $0.4054(5)$ & $0.8820(2)$ & $0.0588(6)$ \\
\hline$U_{\text {eq }}=(1 / 3) \sum_{i} \Sigma_{j} U_{i j} a_{i}^{*} a_{j}^{*}\left(\boldsymbol{a}_{i} \cdot \boldsymbol{a}_{j}\right)$. & &
\end{tabular}

Table 3 Selected bond distances $(\AA)$, angles $\left({ }^{\circ}\right)$ and torsion angles $\left({ }^{\circ}\right)$

\begin{tabular}{|c|c|c|c|c|c|c|c|c|c|}
\hline $\mathrm{O} 1$ & \multicolumn{2}{|c|}{$\mathrm{C} 7$} & \multicolumn{2}{|c|}{$1.373(3)$} & C5 & \multicolumn{2}{|c|}{ C6 } & \multicolumn{2}{|l|}{$1.376(3)$} \\
\hline $\mathrm{Ol}$ & \multicolumn{2}{|c|}{$\mathrm{Cl}$} & \multicolumn{2}{|c|}{$1.384(3)$} & C8 & \multicolumn{2}{|c|}{ C9 } & \multicolumn{2}{|l|}{$1.528(3)$} \\
\hline $\mathrm{O} 2$ & \multicolumn{2}{|c|}{ C7 } & \multicolumn{2}{|c|}{$1.206(3)$} & C9 & \multicolumn{2}{|c|}{ C10 } & \multicolumn{2}{|l|}{$1.455(4)$} \\
\hline N1 & \multicolumn{2}{|c|}{ C7 } & \multicolumn{2}{|c|}{$1.365(3)$} & N1 & \multicolumn{2}{|c|}{ C6 } & \multicolumn{2}{|l|}{$1.399(3)$} \\
\hline Nl & \multirow{2}{*}{\multicolumn{2}{|c|}{$\begin{array}{l}\mathrm{C} 8 \\
\mathrm{C} 10\end{array}$}} & \multirow{2}{*}{\multicolumn{2}{|c|}{$\begin{array}{l}1.451(3) \\
1.139(4)\end{array}$}} & $\mathrm{Cl}$ & \multirow{2}{*}{\multicolumn{2}{|c|}{$\begin{array}{l}\text { C6 } \\
\text { C2 }\end{array}$}} & \multicolumn{2}{|l|}{ 1.384(3) } \\
\hline N2 & & & & & $\mathrm{C} 1$ & & & $1.377(3)$ & \\
\hline C7 & \multicolumn{2}{|c|}{$\mathrm{Ol}$} & $\mathrm{Cl}$ & $107.4(2)$ & C5 & \multicolumn{2}{|l|}{$\mathrm{C} 4$} & C3 & $122.0(2)$ \\
\hline C7 & \multicolumn{2}{|c|}{ NI } & C6 & $109.3(2)$ & C6 & \multicolumn{2}{|l|}{ C5 } & $\mathrm{C} 4$ & $116.1(2)$ \\
\hline C7 & \multirow{2}{*}{\multicolumn{2}{|c|}{ N1 }} & C8 & $123.5(2)$ & C10 & \multicolumn{2}{|l|}{ C9 } & $\mathrm{C} 8$ & $111.3(2)$ \\
\hline N1 & \multirow{2}{*}{\multicolumn{2}{|c|}{$\begin{array}{l}\mathrm{C} 7 \\
\mathrm{C} 1\end{array}$}} & $\mathrm{O}$ & $108.3(2)$ & N2 & \multirow{2}{*}{\multicolumn{2}{|c|}{$\begin{array}{l}\mathrm{C} 10 \\
\mathrm{C} 3\end{array}$}} & C 9 & $177.7(3)$ \\
\hline $\mathrm{C} 2$ & & & 01 & $127.5(2)$ & $\mathrm{C} 2$ & & & $\mathrm{C} 4$ & 121.4(2) \\
\hline C7 & $\mathrm{O} 1$ & $\mathrm{Cl}$ & $\mathrm{C} 2$ & $-177.8(2)$ & $\mathrm{C} 1$ & $\mathrm{O} 1$ & C7 & $\mathrm{O} 2$ & $179.7(2)$ \\
\hline $\mathrm{C} 4$ & C5 & C6 & N1 & $-178.4(2)$ & $\mathrm{C} 1$ & $\mathrm{O} 1$ & C7 & N1 & $-1.0(2)$ \\
\hline $\mathrm{C} 2$ & $\mathrm{Cl}$ & C6 & $\mathrm{C} 5$ & $-1.1(3)$ & C7 & N1 & C8 & C9 & $105.6(2)$ \\
\hline $\mathrm{O} 1$ & $\mathrm{Cl}$ & C6 & $\mathrm{C} 5$ & $179.8(2)$ & C6 & N1 & $\mathrm{C} 8$ & $\mathrm{C} 9$ & $-80.4(2)$ \\
\hline $\mathrm{C} 7$ & N1 & C6 & $\mathrm{C} 5$ & $179.5(2)$ & C6 & N1 & C7 & $\mathrm{O} 2$ & $179.6(2)$ \\
\hline N1 & C8 & C9 & $\mathrm{C} 10$ & $-62.6(3)$ & $\mathrm{C} 8$ & C9 & C10 & $\mathrm{N} 2$ & $25(7)$ \\
\hline
\end{tabular}


<smiles>N#CCCn1c(=O)oc2ccccc21</smiles>

Fig. 1 Chemical structure of 2(3H)-benzoxazolone-3-propionitrile.

except for C9, C10 and N2, are coplanar (r.m.s. deviation 0.032 $\AA$ ). The deviations of $\mathrm{C} 9, \mathrm{C} 10$ and $\mathrm{N} 2$ from the plane defined by $\mathrm{C} 1, \mathrm{C} 2, \mathrm{C} 3, \mathrm{C} 4, \mathrm{C} 5, \mathrm{C} 6, \mathrm{~N} 1, \mathrm{C} 7, \mathrm{O} 1, \mathrm{O} 2$ and $\mathrm{C} 8$ are $1.269(3), 2.255(3)$ and 3.003(3) $\mathrm{A}$, respectively.

The cyanomethyl group is bonded to the benzoxazolone ring through the $\mathrm{C} 8$ atom. According to the values of the related angles (Table 3), the linear chain formed by atoms C9, C10 and $\mathrm{N} 2$ is linked with the planar 2-benzoxazolone moiety. The $\mathrm{N} 1-\mathrm{C} 8-\mathrm{C} 9-\mathrm{C} 10$ torsion angle is $-62.6(3)^{\circ}$.

The bond lengths of the triple bonds agree well with the reported values $[\mathrm{N} 2 \equiv \mathrm{C} 10=1.139(4) \AA]$, which are found in $(5$ chloro-1,3-benzoxazol-2-ylthio)acetonitrile ${ }^{5}$ and also in structure of some new D-secoestrone derivatives. ${ }^{6}$

There are three intermolecular $\mathrm{C}-\mathrm{H} \cdots \mathrm{O}$ hydrogen bonds to $\mathrm{O} 2$ $[\mathrm{C} 8 \cdots \mathrm{O} 2(-x+1 / 2+1, y+1 / 2,-z+1 / 2+1)=3.359(4), \quad \angle \mathrm{C} 8-\mathrm{H} 8 \mathrm{~A} \cdots \mathrm{O} 2$ $=119^{\circ} ; \mathrm{C} 8 \cdots \mathrm{O} 2(x, y+1, z)=3.434(3), \angle \mathrm{C} 8-\mathrm{H} 8 \mathrm{~B} \cdots \mathrm{O} 2=157^{\circ} ; \mathrm{C} 9 \cdots$ $\left.\mathrm{O} 2(-x+1 / 2+1, y+1 / 2,-z+1 / 2+1)=3.108(3), \angle \mathrm{C} 9-\mathrm{H} 9 \mathrm{~A} \cdots \mathrm{O} 2=120^{\circ}\right]$ and a $\mathrm{C}-\mathrm{H} \cdots \mathrm{N}$ hydrogen bonds to $\mathrm{N} 2 \quad[\mathrm{C} 3 \cdots \mathrm{N} 2$ $\left.(x+1 / 2,-y+1 / 2, z-1 / 2)=3.468(4), \angle \mathrm{C} 3-\mathrm{H} 3 \cdots \mathrm{N} 2=147^{\circ}\right] . .^{7,8} \quad$ The closest $\mathrm{H} \cdots \mathrm{O}$ distance is the intramolecular $\mathrm{H} 8 \mathrm{~A} \cdots \mathrm{O} 2$ of $2.58 \AA$ interaction. ${ }^{9}$

\section{Acknowledgements}

The authors wish to acknowledge the purchase of the CAD4 diffractometer under Grant DPT/TBAG1 of the Scientific and Technical Research Council of Turkey.

\section{References}

1. G. M. Sheldrick, SHELXS-97. Program for the Solution of

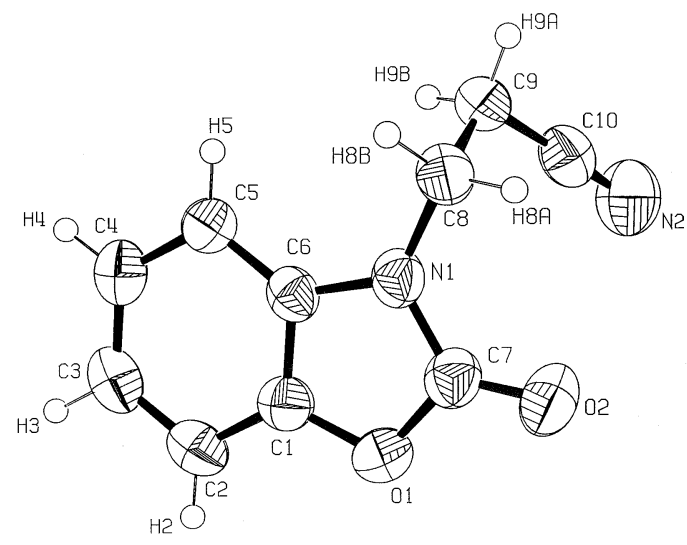

Fig. 2 Perspective view of the molecular structure of the title compound with the atom numbering scheme. The displacement ellipsoids are plotted at the $50 \%$ probability level.

Crystal Structures, 1997, Univ. of Göttingen, Germany.

2. G. M. Sheldrick, SHELXL-97. Program for the Refinement of Crystal Structures, 1997, Univ. of Göttingen, Germany.

3. G. Mairesse, J. C. Boivin, M. C. Bermann, J. P. Bonte, and D. J. Thomas, Acta Crystallogr., 1984, C40, 1019.

4. G. Mairesse, J. C. Boiven, D. J. Thomas, J. P. Bonte, D. Lesieur, and C. Lespagnol, Acta Crystallogr., 1984, C40, 1432.

5. Ö. Ergin, R. Sillanpää, C. Şafak, and İ. Çalıs, Acta Crystallogr., 1994, C50, 933.

6. S. Stanković, J. Petrović, D. Miljković, V. Pejanović, R. Kovačević, A. Stefanović, and M. Bruvo, Acta Crystallogr., 1992, C48, 1248.

7. R. A. Lalancette, A. P. J. Brunskill, and H. W. Thompson, Acta Crystallogr., 1999, C55, 568.

8. L. M. Fitzsimons and J. F. Gallagher, Acta Crystallogr., 1999, C55, 472.

9. M. Nardelli, Comput. Chem., 1983, 7, 95. 